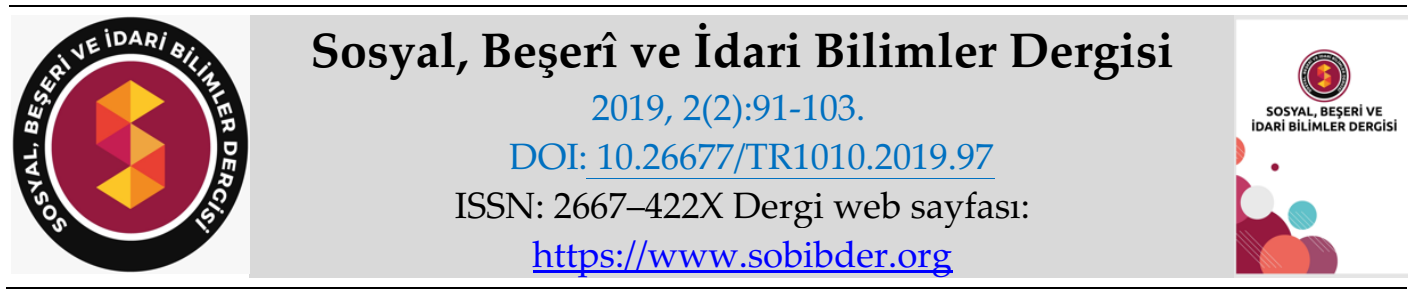

KAVRAMSAL MAKALE

\title{
Müşteri İlişkileri Yönetiminin Evrimi: İnsanlar, Süreç ve Teknoloji
}

Dr. Sinem KUNT, Çankırı Karatekin Üniversitesi, Ilgaz Turizm ve Otelcilik Yüksekokulu, Çankırı, e-posta: sinemkunt@karatekin.edu.tr

ORCID: https://orcid.org/0000-0002-5342-4734

Prof. Dr. Azize HASSAN, Ankara Hacı Bayram Veli Üniversitesi, Turizm Fakültesi, Ankara, eposta: azize.hassan@hbv.edu.tr ORCID: https://orcid.org/0000-0003-2509-1415

Öz

Bu çalışmanın amacı müşteri ilişkileri yönetiminin evrimini insan, süreç ve teknoloji faktörlerini inceleyerek ortaya koymaktır. Dünyada değişimlerin hızlı yaşanmasına bağlı olarak müşteri ilişkileri yönetimi anlayışında da değişimlerin ortaya çıktığı gözlenmektedir. Bu bağlamda müşteri ilişkilileri anlayışında gözlenen değişimleri ve gelişmeleri insan, süreç ve teknoloji faktörlerini dikkate alarak incelemek önem taşımaktadır. Araştırma literatür taramasına dayanarak oluşturulmuş ve öneriler sunularak zenginleştirilmiştir. Elde edilen bulgulara göre teknoloji alanındaki ilerlemeler, müşterilerin satın alma davranış kalıplarının değişmesi, rekabetin artması, tehdit ve fırsatları önceden tahmin ederek onları ortadan kaldırmaya yönelik stratejilerin geliştirilmesi gibi faktörler neticesinde müşteri ilişkileri yönetimi işletmeler için tekrar önem kazanmıştır. Bu noktada araştırmada, müşteri ilişkileri yönetimi konusu ayrıntılı bir şekilde ele alınmış ve elde edilen bulgular doğrultusunda müşteri ilişkilileri yönetimine dair önerilerde bulunulmuştur.

Anahtar Kelimeler: Pazarlama, İlişkisel Pazarlama, Müşteri İlişkileri Yönetimi.

Makale Gönderme Tarihi: 09.03.2019

Makale Kabul Tarihi: 13.04.2019

\section{Önerilen Atıf:}

Kunt, S. ve Hassan, A. (2019). Müşteri İlişkileri Yönetiminin Evrimi: İnsanlar, Süreç ve Teknoloji, Sosyal, Beşeri ve İdari Bilimler Dergisi, 2(2):91-103.

(c) 2019 Sosyal, Beşerî ve İdari Bilimler Dergisi. 


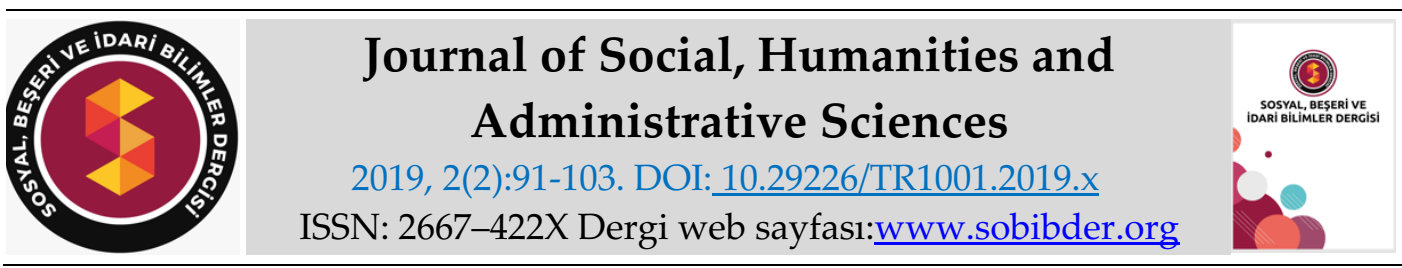

\title{
CONCEPTUAL PAPER
}

\section{The Evolution of Customer Relationship Management (CRM): People, Process and Technology}

Dr. Sinem KUNT, Çankırı Karatekin University, School of Ilgaz Tourism and Hotel Management, Çankırı, e-mail: sinemkunt@karatekin.edu.tr

ORCID: https://orcid.org/0000-0002-5342-4734

Prof. Dr. Azize HASSAN, Ankara Hacı Bayram Veli University, Facult of Tourism, Ankara, email: azize.hassan@hbv.edu.tr

ORCID: https://orcid.org/0000-0003-2509-1415

\begin{abstract}
The purpose of this study is to examine the evolution of customer relationship management by examining people, process and technology factors. It is observed that changes in the understanding of customer relationship management have emerged due to the rapid changes in the world. In this context, it is important to examine the changes and developments observed in the understanding of customer relations, taking into account the factors of people, process and technology. The research was based on literature review and the proposals were presented and enriched. According to the findings, the progress in technology has made customer relationship management re-importance for businesses as a result of factors such as customers' changing behavior patterns, increasing competition and need of developing proactive strategies. At this point, proposals have been made for the successful management of customer relationships in the research.
\end{abstract}

Keywords: Marketing, Relationship Marketing, Customer Relations Management.

Received: 09.03.2019

Accepted: 13.04 .2019

\section{Suggested Citation:}

Kunt, S. and Hassan, A. (2019). The Evolution of Customer Relationship Management (CRM): People, Process and Technology, Journal of Social, Humanities and Administrative Sciences, 2(2):91103.

C 2019 Sosyal, Beşerî ve İdari Bilimler Dergisi. 


\section{GíRiş}

19. yüzyılın ortalarında ürünün tüketiciler için ulaşılabilirliğinin artması sonucu kitle üretim teknikleri ve kitle pazarlama anlayışının değişikliğe uğradığı gözlenmektedir (Chen ve Popovich, 2003). Günümüzde hemen hemen her üretici firmanın karşı karşıya kaldığı en temel problem artan rekabet ve pazar dinamizmi neticesinde birbirinin ikamesi ürünlerin daha ucuz fiyata ve daha cazip seçenekler ile tüketicilere sunulmasıdır. Bunun sonucu olarak müşteri sadakatinin önemli ölçüde azalması, kar marjlarının düşmesi ve işletmelerin varlıklarına devam edememe sorunu gündeme gelmektedir. Bu noktada müşteri ilişkileri yönetimi (MİY) pazarlama açısından bir devrim niteliği taşımaktadır (Kırım, 2003). İşletmeler müşteri ilişkileri yönetimi süreçlerini başarılı bir şekilde yönetebildiği ölçüde müşteri sadakatini, müşteri yaşam boyu değerini ve kar marjlarını artırmaktadırlar.

Son yıllarda hızla ilerleyen teknoloji sayesinde üretim maliyetlerinin düşmesi, mal ve hizmetlerin kolayca taklit edilmesi, müşteri sadakatinin azalması, marka bağımlılığının giderek azalması gibi unsurlar rekabet unsurlarını tetiklemiştir. Satış noktasında satılan mal ve hizmetin kalitesi ya da satış sonrası verilen hizmetlerle birlikte müşteri ilişkileri çok daha fazla önem kazanmıştır.

Teknolojik gelişmeler ve diğer uygulamalar çok kısa sürede taklit edilmekte ve bu durum işletmelerin rekabet üstünlüğünü uzun süre koruyamamasına neden olmaktadır. Kuruluşunun uzun ve zahmetli olmasına rağmen MiY ise taklit edilmesi zor ve rekabet avantajı sağlaması açısından işletmelere pek çok açıdan fayda sağlamaktadır. Bu durum gelecekte rekabetin yoğun biçimde müşteri ilişkileri yönetimi üzerinde olacağının göstergesidir. Bu bağlamda MiY'in gelişimini insan, süreç ve teknoloji faktörlerini inceleyerek ortaya koymanın işletmeler için uzun vadede strateji belirleme ve geleceğe dönük pazarlama faaliyetleri konusunda faydalı olacağı düşünülmektedir.

\section{MÜŞTERİ İLIŞKİLERI YÖNETIMINNIN EVRIMMI}

Alvin Toffler'a göre insan uygarlığı ekonominin geçirdiği aşamalara göre üç dalgaya ayrılmaktadır. Birinci dalga, en önemli sermayenin üzerinde tarım yapılan toprak olduğu tarım çağıdır. İkinci dalga, İngiltere ve Avrupa'daki sanayi devriminin ardından gelen sanayileşme çağıdır. Üçüncü dalga ise, akıl, enformasyon ve ileri teknolojinin sermayeyi oluşturduğu enformasyon çağıdır (Kotler, Kartajaya ve Setiawan, 2014: 7).

Pazarlamanın son 60 yılına bakıldığında da insan uygarlığının gelişmesine paralel benzer değişimlerin yaşandığını söylemek mümkündür. İnsanların temel ihtiyaçlarını kendilerinin yeterli ölçüde karşılayabildiği dönemlerde pazarlama kavramından söz edilememektedir. Ancak toplumun sosyo-ekonomik bir düzene dönüştüğü iş bölümünün gelişmesi, sanayileşme akımı ve nüfusun kentleşmesi sonucu pazarlama doğmuştur. Bu bağlamda pazarlama bir devrim olmaktan çok bir evrim sonucu ortaya çıktığı ifade edilmektedir (Cemalcılar, 1986). Tüketici istek, ihtiyaç ve beklentilerinin farkına varma veya keşfetme yeteneği olan pazarlama, dünya genelinde yaşanan ekonomik, teknolojik ve siyasi değişimlerden beslenmekte aynı zamanda etkilenmektedir.

Kısaca özetlemek gerekirse pazarlama söz konusu değişimlere bağlı olarak üç temel disiplin etrafında evrim geçirmiştir. Bunlar: ürün yönetimi, müşteri yönetimi ve marka yönetimidir. Pazarlama kavramları 1950'lerde ve 1960'larda ürün yönetimine odaklanırken, 1970'ler ve 80'lerde müşteri yönetimine odaklanmıştır. 1990'lar ve 2000'lerde de marka yönetimi disiplini 
eklenmiştir. Görüldüğü üzere, pazarlama anlayışları sürekli insan yaşamının farklı alanlarına uyarlanmıştır ve değişikliğe uğramıştır (Kotler vd., 2014:37).

Ürün ve marka arasında bir geçiş dönemi olan müşteri ilişkilerini anlamak pazarlamanın özünü oluşturmakta ve bir ürün veya hizmetin marka kişiliği kazanmasında rol oynamaktadır. Müşteri ilişkileri veya bire bir pazarlama (Peppers ve Rogers, 1999) yeni bir kavram olmamakla birlikte kökeninin ilişkisel pazarlamaya dayandığı söylenmektedir (Chen ve Popovich, 2003). Pazarlama kısaca üretim, ürün, satış, pazarlama ve ilişkisel pazarlama gelişimi (Karafakığlu, 2005) çerçevesinde ve dünya üzerinde yaşanan ekonomik, teknolojik, kültürel ve politik faktörler neticesinde farklı boyutlar kazanmıştır. Bu noktada ilişkisel pazarlama uzun dönem karlılığı artırmak üzere müşteriler ile ilişkilerin kurulması, geliştirilmesi ve yönetilmesi şeklinde ifade edilmektedir.

MiY ilk olarak 1990'lı yılların başında Amerika Birleşik Devletleri ve İngiltere'de küçük ölçekli finans kuruluşlarının özel çözümler üretmek üzere büyük bankaların müşterilerinin kendi bünyelerine çekmeleriyle ortaya çıkmıştır. MiY'in yeni bir iş anlayışı haline gelmesi ise son yıllarda "müşteri merkezlilik" anlayışı çerçevesinde geliştirilen teknolojinin yaygınlaşması ile gerçekleşmiştir.

MIY, müşterileri yakından tanıyarak müşterilerin farklı özelliklerini keşfetmek ve bu farklılıkları her bir müşteriye göre işletme için bir stratejiye dönüştürebilme fırsatı sağlamaktadır. Özünde farklı müşterilere farklı muamele yapın gibi basit bir özdeyişi barındırmasına karşın müşteri ilişkileri yönetiminin uygulanması kolay olmamaktadır. Bunu başarı ile uygulayabilen işletme sayısı da oldukça sınırlı sayıda olduğu ifade edilmektedir (Kırım, 2003:47).

MIY ile ilgili açık kavramsal bir çerçevenin veya görüş birliğinin henüz olmadı̆̆ı ifade edilmektedir (Zablah, Bellenger ve Johnston, 2004). Bu bağlamda MiY kavramı şu şekilde özetlenebilmektedir: MIY, müşteriler ile bilgi temelinde değer yaratan ilişkiler kurmayı ve geliştirmeyi amaçlayan bir iş stratejisidir. Mİ, müşteri ile temas kurabilmek için bilgi teknolojileri yardımıyla faaliyetlerin ve süreçlerin yeniden tasarlanmasını gerekli kılmaktadır. Böylece, ürünler ve hizmetler kişiselleştirerek, firma müşteri ihtiyaçları en iyi şekilde karşılanabilmekte, uzun vadeli ve karşılıklı yarar sağlayan sadakat ilişkileri kurulabilmektedir (Garrido-Moreno ve Padilla-Meléndez, 2011:438). Diğer bir ifade ile müşteri beklentilerini daha fazla anlamak için gerekli verileri toplamaya ve elde edilen bilgiler ışığında yeni çalışma stratejileri geliştirmeye MIY, bu yönde geliştirilen yazılımlara da Mi̇Y programı ya da müşteri takip programı adı verilmektedir. Stratejik MiY ile işletmeler müşteri amaçlarını tanımlamakta ve karlılığını belirlemektedir. Bu durum strateji geliştirme ve değer yaratma ile ilgili bir düzeyi ifade etmektedir. İşletmeler teknolojiden faydalanarak müşteri tatmini sağlamada ve müşteri yaşam boyu değeri temelinde müşteriler ile stratejik ilişkiler gerçekleştirmektedir. Bu bağlamda söz konusu ilişkilerin yönetilmesi stratejisi MIYY olarak ifade edilmektedir. Tablo 1'de görüleceği üzere müşteriler dünyanın dört bir yanına dağılmış durumdadır. Müşteriler ile müşteri temas noktalarını kullanarak etkili iletişim kurmak müşteriye özgü bilgilerin elde edilmesini ve davranışlarının anlaşılmasını sağlamaktadır. Pazarlama, satış ve hizmet gibi ön ofis süreçleri ile müşteri ilişkileri uygulamaları otomatikleşmekte, daha verimli hale gelmekte ve işlevsel bir özellik kazanmaktadır. MiY'in etkin bir şekilde uygulanması; işletmelerin karlılığını, verimliliği artırmakta, rakiplerinden farklılaşmasına yardımcı olmakta ve müşteri beklentilerinin karşılanmasını sağlamaktadır. Sonuç olarak bu uygulamalar işletmelerin maliyetlerini düşürmesine olanak sağlamaktadır. 
Tablo 1: MiY Uygulamaları

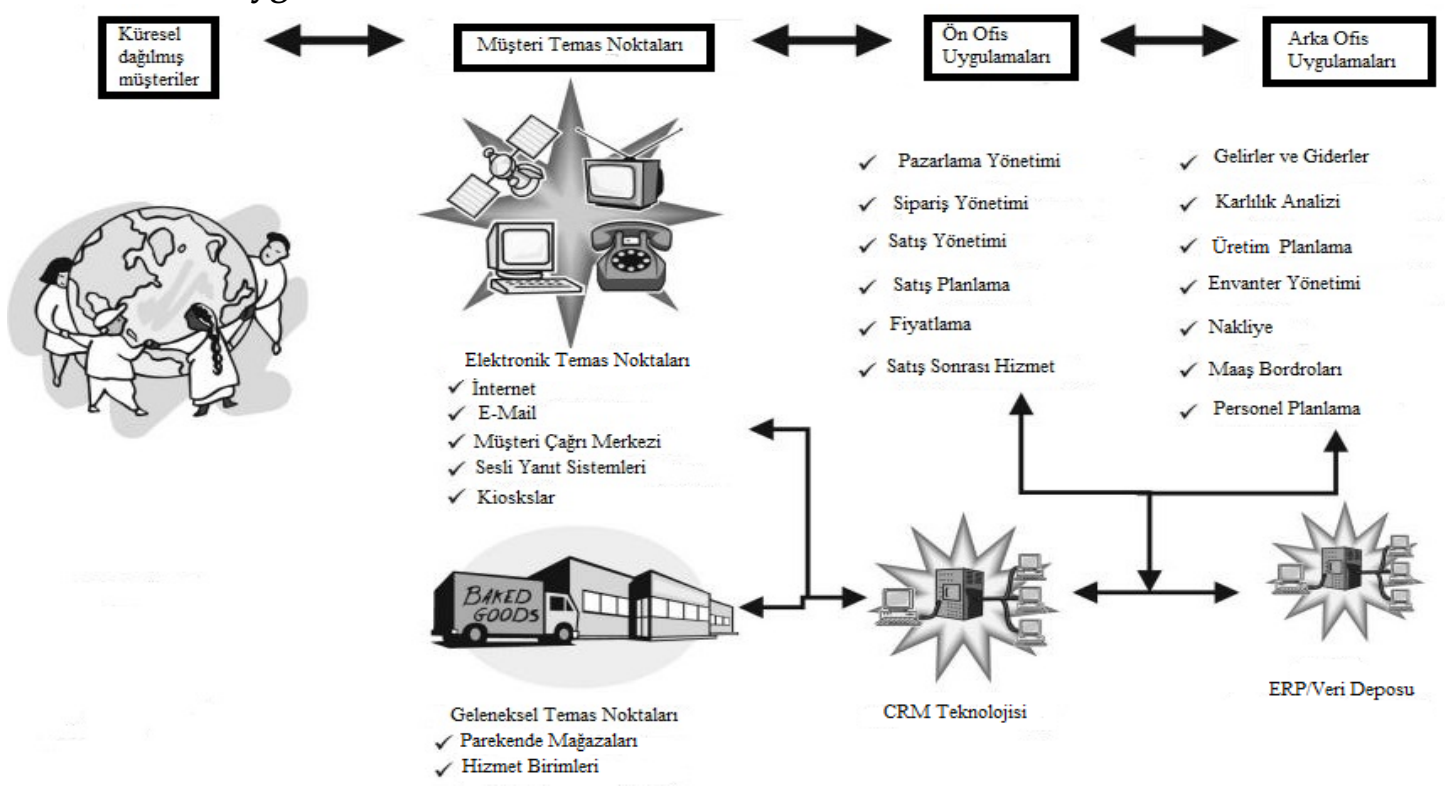

Kaynak: Chen ve Popovich, (2003:674)

MIYY ile ilgili literatür taraması yapıldığında MIYY anlayışının insanlar, süreç ve teknoloji faktörleri çerçevesinde evrim geçirdiği gözlenmektedir.

İnsanların $X, Y$ ve $Z$ şeklinde kuşaklara ayrıldığı günümüzde satın alma davranış kalıpları da değişmektedir. Değişen satın alma davranışlarına yönelik tüketiciler ile iletişim süreçlerini yönetmek zorlaşmaktadır. Diğer taraftan 1970'lerden 1990'lara kadar geçen süreçte teorik olarak kavramsallaştırılmaya çalışılan MIY özellikle 2000'li yıllardan sonra yazılım teknolojilerindeki girişimlerde yaşanan gelişmelere bağlı olarak daha geniş bir uygulama alanı bulduğu söylenmektedir. Yazılım programları müşteri temaslarını izleme ve tahmin etmede konusunda yardımcı olmaktadır.

Günümüzde hızlı bir şekilde gelişme gösteren MİY'in yaşadığı evrimi insanlar, süreç ve teknoloji alt başlıkları ile incelemek araştırmada önem taşımaktadır. Bu bağlamda aşağıda literatür taramasına dayanarak oluşturulmuş insan, süreç ve teknoloji faktörlerine ilişkin detaylı bilgilere yer verilmiştir.

\section{İnsan Faktörü}

Beşeri bir varlık olan insanın istek, ihtiyaç ve beklentileri dünya üzerinde yaşanan değişimlere bağlı olarak sürekli değişmektedir. Ne üreteceğinden başlayıp, nasıl duyuracağına ve kalıcı ilişkiler geliştireceğine kadar geçen tüm süreç içinde çıkış noktası olarak "insan" ele alınmaktadır. İnsan merkezlilik kavramı Mİ'de müşteri merkezlilik kavramı ile karşılık bulmaktadır. Ancak müşteri merkezlilik müşteri odaklılık anlamına gelmemektedir. Zira müşteri odaklılık toplam kalite anlayışının odaklandığı bir kavramdır ve "ne üreteceğine karar ver kitlesel olarak pazarla" anlayışını ifade etmektedir. Diğer yandan müşteri merkezlilik, müşteri kitlesinin çok küçük pazar dilimlerine ayırmak ve her bir pazar dilimlerine ayrı bir strateji uygulamayı ifade etmektedir (Kırım, 2003). 
İnsan davranışlarını daha iyi anlayabilmek için nesillerin kuşaklara ayrıldığı bilinmektedir. Kuşak kavramı, "aynı dönemlerde yaşayan, ortak özelliklere sahip bireylerin oluşturduğu gruplar olarak" (Adıgüzel, Batur ve Ekşili, 2014:167) tanımlanmaktadır. Bu çalışmada X, Y ve Z kuşağını kısaca tanımlamakta ve satın alma davranış kalıpları hakkında bilgiler sunulmaktadır.

Nesillerin ayrıldığı ilk kuşak X kuşağıdır. Bu kuşak, 1965 ile 1979 yılları arasında doğanlar olarak sınıflandırılırlar (Alwin, 2002). X kuşağı bireyleri, teknoloji ve bilgi ile barışık, girişimci, amaç odaklı ve bağımsızdırlar (Jianrui, 2011).

İkinci kuşak Y kuşağıdır. Lower'a (2008) göre bu kuşağın doğum yılları aralığı herhangi bir gösterge ile kısıtlanmamaktadır. Pek çok uzman, 1980 ile 2001 yılları arasında doğanlar için bu kuşak ismini kullanmaktadır. Sosyal medyanın etkisiyle büyüyen ilk kuşak olma özelliğine sahip Y kuşağıdır. Bu kuşağın üçte ikisi, beş yaşından önce bilgisayarla tanışmaktadır. Bu kuşak, arkadaşlarına, ailelerine, akrabalarına her an ulaşmanın yanı sıra bilgilere ve eğlenceye de her dakika ulaşabilmektedir. Her ne kadar küresel ekonomik krizden diğer kuşaklara kıyasla daha kötü etkilenmelerine karşın iyimserliklerini muhafaza etmektedirler. Kuşağın diğer özellikleri ise ilgi odağı olmaya alışık olmaları, beklentilerini yüksek tutmaları ve hedeflerini açık bir şekilde tanımlamaları şeklinde sıralanabilmektedir.

Son kuşak ise Z kuşağıdır. 2000-2020 yılları arasında dünyaya geldiğine ve geleceğine inanılan bu kuşağın ilk üyeleri önümüzdeki beş sene içerisinde çalışma yaşamına gireceği ifade edilmektedir (Adıgüzel vd., 2014). 'İnternet kuşağı' olarak da adlandırılan bu kuşak, yeni teknolojik imkânlarla iletişim ve ulaşım kolaylıkları ile hep bir arada bulunmaktadır. Bu kuşak önceki kuşaktan farklı olarak 'network' gençleri, çeşitli ağların üyeleri olabilmektedirler. Uzaktan da ilişki kurabildikleri için yalnız yaşadıkları ve yaşayabilecekleri savunulmaktadır (Adıgüzel vd., 2014). Aynı anda birden fazla konu ile ilgilenebilme becerilerini geliştirdikleri söylenebilmektedir. Örneğin yapılan bir araştırmaya göre gelecekte söz konusu üç kuşağın birleşerek aynı iş yerinde çalışacağ ifade edilmektedir. Buna rağmen kuşaklar arasında liderlik tutkusu, girişimcilik arzusu, teknolojiye güvenme, eğitim ve uyum sağlama konularında farklar tespit edilmiştir. Şirketlerin ve liderlerin; liderlik gelişimi, teknoloji, eğitim ve kültür oluşturma hakkında daha iyi kararlar alabilmeleri için bu kuşak arasındaki farkları iyi tespit etmeleri tavsiye edilmektedir (Bresman ve Rao, 2017).

Tüketicilere ürün ve hizmet pazarlayanlar açısından söz konusu kuşaklara yönelik pazarlama faaliyetleri de farklılaşmaktadır. Diğer taraftan bu kuşakların ortak noktası teknolojiye adapte olma sorunu yaşamamalarıdır. Bu bağlamda ürün ve hizmetlerini bu kuşaklara sunmak için teknolojiyi kullanma pazarlamacılar açısından bir fırsat değeri taşımaktadır. Güncel bir çalışmaya göre günümüz tüketicilerini etkilemek için bazı stratejiler bulunmaktadır (Köse ve Yengin, 2018). Buna göre:

- Tüketicilerin farklı veya özel olduklarını hissettirmek,

- Pazarlama karması elemanlarının onların gereksinimlerine ve fikirlerine göre uyarlanmasını sağlamak,

- Onlara geleneksel reklamdan ziyade teknoloji aracilığıyla ulaşmak,

- Hızlı tüketip, hızlı yaşayan X, Y ve Z kuşaklarına sunulan içeriklerin durağan ve stabil olmamasına özen göstermek,

- Tükettikleri her şeyden çabuk sıkılan yeni nesili eğlendirmeyi amaçlamak,

- Oyunlaşan yaşam şekilleri sunun veya oyunlaştırılmış uygulamalar yer vermek,

- Üre-tüketici kavramını pazarlama faaliyetleri ile kişiselleştirmek, 
- Dikkatlerini çekecek ve sıkılmadan tüketecekleri içerikler için teknolojik uygulamalardan yararlanmak,

- Uzun reklamlar yerine fijital (dijital ve geleneksel pazarlama yöntemlerinin birlikte kullanımı) reklamları kullanmak ve

- Tüketicilerin ilgi alanlarını, vakit geçirdikleri ortamları ve kullandıkları iletişim araçlarının neler olduğunu tespit etmektir.

Günümüz teknolojisinde tüketicilere ulaşmak zor olmasa da onları ikna etmek ve dikkatlerini çekmek zorlaşmaktadır. Bu noktada gelişen teknoloji ve davranış kalıplarını sürekli izleyen ve bunları ürün veya hizmete dönüştürme olanağı bulan işletmelerin rekabet ortamında tehdit ve fırsatları önceden öngörebilecek (proaktif) bir avantaja sahip olacakları söylenebilmektedir.

\section{Süreç Faktörü}

Yakın bir zamana kadar etkili tesisleri ve fazla kaynakları olan işletmeler müşteri ihtiyaçlarını standart ürünler ile daha düşük maliyet ile karşılama konusunda avantajlı konumdaydılar. Bu bağlamda kitle pazarlama ve kitle üretim anlayışının müşteriler memnun kaldığı sürece başarılı olduğu gözlenmektedir. Ancak, daha fazla işletme pazara girdikçe ve müşteri memnuniyeti azaldıkça kitlesel pazarlama teknikleri etkinliğini kaybetmeye başlamıştır. Bu noktada, işletmeler heterojen pazarları dilimlere ayırmaya çalışmaktadırlar. Değişen müşteri ihtiyaçları ve tercihleri doğrultusunda işletmelerin müşterilerini daha küçük tanımlamaları ve daha küçük bölümlere ayırmaları zaruri hale gelmektedir. İşletmelerin müşteri gereksinimlerini karşılama çabaları hedef pazarlama veya bölümlendirme yaklaşımları şeklinde tanımlanmakta ve pazarlama literatüründe yerini almaktadır (Gupta, Aggarwal ve Rani, 2016; Law, Fong ve Chan, 2018; Pohludka ve Stverkova, 2019; Umamaheswari, Pandian ve Venkateswari, 2018).

Başka bir açıdan yeni müşteri kazanmanın maliyetinin müşteriyi elde tutmanın maliyetine göre daha az olduğu bilinen bir gerçektir. Dolayısıyla ilişkisel pazarlama müşterilerin ihtiyaçlarının, önceliklerinin, satın alma davranışlarının ve fiyat hassasiyetlerinin değişmesine paralel olarak gelişme göstermektedir.

Tablo 2'de görüleceği üzere müşteriler ile ilişkiler zaman içinde değişmiştir. Kitlesel pazar çevresinde oluşturulan pazarlama karması faaliyetleri zaman içinde pahalı bir müşteri kazanma yolu olmuştur.

İşletmeler kitlesel pazarları daha küçük pazarlara ayırmaya başlamıştır. Sonrasında ise pazar payının değil müşteri payının önemli hale gelmesi, müşteri memnuniyeti ve müşteri sadakati kavramlarının ön plana çıkması ile birlikte müşteriyi elde tutma çabalarına gerek duyulması sonucu her müşterinin özel ihtiyaçlarına göre hitap etme stratejileri oluşturulmaya başlanmıştır. Pazar ve müşteri anlayışındaki değişimler ve teknolojik gelişmeler ile birlikte Mi̛Y günümüzde pek çok işletme tarafından uygulanan bir iş stratejisi olarak görülmektedir. 


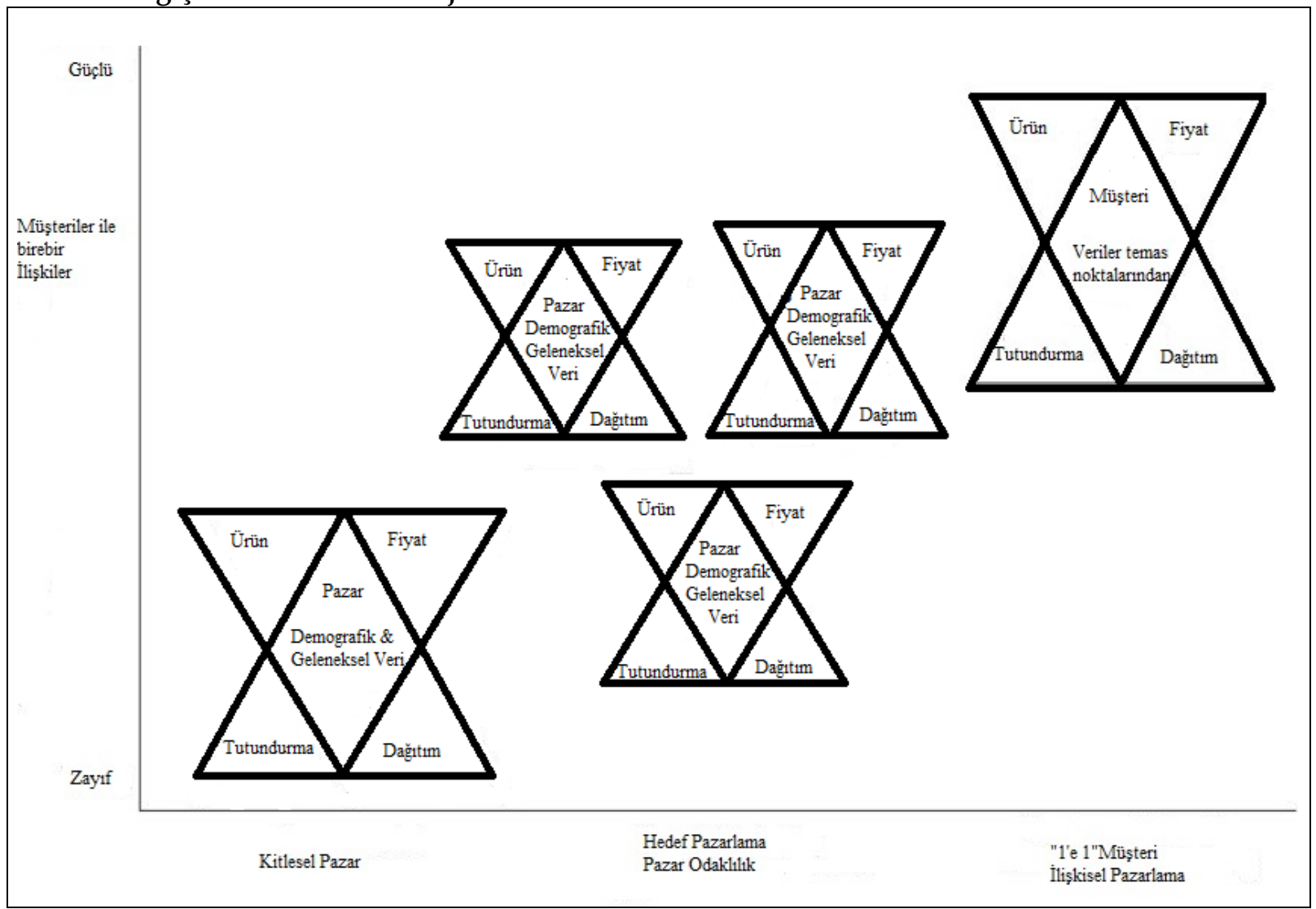

Kaynak: Chen ve Popovich, (2003:683)

\section{Teknoloji Faktörü}

Yüz yıl önce elektrik, sayısız endüstrinin kurulmasını ve gelişmesini sağlamıştır. Bilişim teknolojileri ve internet ise bu gelişmeyi 20 yıl kadar önce yapmıştır. 5 yıl sonra ise yapay zekanın aynı ilerlemeyi ve dönüşümü yapması beklenmektedir $(\mathrm{Ng}, 2016)$.

İkinci Dünya Savaşı'ndan sonraki dönemlerde teknoloji alanında büyük gelişmeler yaşanmıştır. Söz konusu gelişmeler ile birlikte bilim insanlarının, mühendislerin ve teknik elemanların çalışmaları da işletmelerin pazarlama faaliyetlerini büyük oranda etkilemeye başlamıştır. Diğer taraftan ortaya çıkan gelişmelerin pazarlama üzerindeki etkisi tüketicilerin yaşam biçimlerinden harcama modellerine ulaşım ve haberleşme sistemlerinden günlük yaşamlarına kadar yansımaktadır (Mucuk, 1997). Dolayısıyla değişen tüketici anlayışı ve pazarlama faaliyetleri pazarlama yöneticilerinin gelişmeleri yakından takip etmesini gerekli kılmaktadır. Ancak yeniliği üretmenin veya bulmanın yeterli olmadığı söylenmektedir.

Yeni mal ve hizmetlerin tüketici ihtiyaç, istek ve beklentilerine uygun hale getirilmesi ve tüketicilere benimsetilmesi önem taşımaktadır. Dolayısıyla pazarlama ve teknoloji karşılıklı etkileşim halinde bir gelişme göstermektedir. Bu noktada bir şirketin müşteri ile olan ilişkilerini düzenli bir şekilde yönetilmesine yardımcı olan MIY, yazılım ve internet yetenekleri için kullanılan bir bilişim endüstrisi terimi olarak karşımıza çıkmaktadır. MIY, müşteri ile ilgili tek ve kapsamlı bir bilgi üretmek üzere verilerini müşteri dokunma noktalarından alan, karlı müş̧erileri tespit eden, satın alma potansiyellerini öngören ve elde ettiği tüm verileri bir strateji doğrultusunda işleyen karışık ve çok yönlü uygulamalar gerektiren bir yaklaşım olarak ifade 
edilmektedir (Chiang, 2018). Bu noktada teknoloji işletmelere müşteri davranışlarını kolay bir şekilde izlemede, tanımlamada ve analiz etmede yardımcı olmaktadır. Bu sayede en iyi müşteriler tespit edilmekte ve belirlenen müşteri grubu için belirlenen pazarlama faaliyetlerine odaklanılmaktadır.

Teknoloji faktörü işletmelerin müşterilerini tutmada karşılıkll, etkili ve etkin bir iletişim sağlamaktadır. Teknolojideki yenilikler, rekabet çevreleri ve internet müşteriler ile birebir ilişki kurmayı gerekli kılan faktörlerden sadece bir kaçıdır. İşletmeler teknolojinin sunmuş olduğu imkanlardan faydalanarak müşterilerine alışveriş deneyimi, online satış, ayrıcalıklı teklifler ve hizmetler de sunabilmektedirler (Rodriguez, Peterson ve Krishnan, 2018).

İster üretici, isterse toptancı, ihracatçı ve ithalatçı olsun, bir işletmenin rakiplerinden farklılaşması, pazar çevresinde lider konuma gelmesi veya pazardaki payını koruyabilmesi, müşterilerinin kısa ve uzun vadeli beklentilerine cevap verebilmesi için kendini sürekli yenilemesi kaçınılmaz olmaktadır. Zira, küreselleşen dünyada küçük, orta ve büyük tüm kuruluşların pazar paylarını ancak teknolojilerini geliştirerek koruyabilecekleri ifade edilmektedir (Karafakığlu, 2005).

Sayıca az müşteriler ile bire-bir ilişkiler şahsi olarak kurulabilirken, fazla sayıda müşteri ile benzer ve hatta çok daha ileri ilişkileri başlatabilmenin kişisel olarak imkanı olamamaktadır. Bu noktada teknoloji devreye girmektedir. Kurumların müşterileri ile uzun dönemli bir öğrenen ilişki diğer bir ifade ile müşteriyi kümülatif olarak tanımak üzerine kurulu bir ilişki geliştirebilmeleri için 3 tür teknolojiye ihtiyaçları vardır. Bunlar; veri tabanı, interaktif medya ve ssmarlama seri üretim teknolojisi şeklinde ifade edilmektedir.

Veri tabanı: her birim müşterinin işletme ile yapmış olduğu işlemlerin ve kurduğunu ilişkilerin sistemsel hafızaya alınmasıdır. İnteraktif medya ise çağrı merkezleri, web siteleri, satış otomasyonu ve sosyal medya gibi paylaşım ağların ifade etmektedir. Son olarak ısmarlama seri üretim teknolojisi her müşteriye farklı muamele yapabilmeyi ve ürünleri bireysel farklılıklara uyarlayabilmek için gerekli olan dijital teknoloji kullanmayı ön görmektedir. Bu teknoloji türleri ile müşterilerin ihtiyaç, istek ve beklentilerini belirleyebilmek mümkün olmaktadır.

Geleceğin teknolojisi ise "Yapay Zeka" üzerine inşa edilmektedir. Yapay zeka henüz olgunlaşmamış ancak hızla gelişmekte olan bir teknolojik gelişimdir. İnsan beyninin yaptığı her şeyi ve daha fazlasını yapabilme kapasitesine sahip yapay zeka günümüzde büyük şirketler tarafından kullanılmaktadır (Google, Stanford, Baidu). Bilişim teknolojileri ve internet günümüzde çok miktarda veri oluşturmaktadır. Yapay zekanın bu verileri bir değere dönüştürme gücüne sahip olduğu düşünülmektedir. Bu doğrultuda bir strateji oluşturmak isteyen işletmeler yapay zeka bilgi ve yeteneğine sahip CEO'ları işe almaktadır. Ng (2016), en başarılı yapay zeka kullanan işletmelerin bazılarına takım liderliği yapmaktadır. Bu noktada yapay zeka liderlerinin sahip olması gereken özellikleri birkaç maddede özetlemektedir:

\section{a) Yapay zeka ve veri altyapısının teknik anlayışı}

Yapay zeka üzerine çalışan liderlerin makine öğrenim sistemlerini kurmalarını ve yönetebilmelerini sağlayacak bilgi ve beceriye sahip olması beklenmektedir. Yapay zeka çağında veri altyapısı önemlidir. Şirket liderlerinin veri tabanlarını nasıl düzenlediği ve ilgili tüm verilerin güvenli ve erişilebilir şekilde nasıl depolandığı konusunda bilgi sahibi olması beklenmektedir. 


\section{b) Fonksiyonel olarak çalışma yeteneği}

Yapay zekanın kendisi bir ürün veya iş olmamakla birlikte daha ziyade mevcut iş alanlarına yardımcı olabilecek ve yeni ürünler ya da iş kolları yaratabilecek temel bir teknolojik gelişme olduğu ifade edilmektedir. Bu nedenle, farklı iş ünitelerini veya fonksiyonel ekipleri anlama ve bunlarla çalışma yeteneği önem kazanmaktadır.

\section{c) Güçlü girişimcilik yetenekleri}

Yapay zeka kendi kendine giden araçlardan sohbet edilebilecek robotlara kadar yeni ürünler üretme fırsatları yaratmaktadır. Girişimcilik faaliyetlerini yönetebilen bir liderin, sektör için bu tür yenilikleri başarılı bir şekilde oluşturma olasılığını artıracağı ifade edilmektedir.

\section{d) Yapay zeka yeteneğini korumak ve çekici hale getirmek}

Yapay zeka yeteneğine sahip liderde bu madde en son aranmaktadır. Yeni üniversite mezunları arasında, yapay zeka konusunda uzmanlaşmış öğrencilerin maaşlarında net bir farklılık görünmektedir. İyi bir yapay zeka yöneticisinden ilginç projeleri vurgulaması ve takım üyelerine yeteneklerini geliştirmeye devam etme şansı sunarak yeteneklerin nasıl korunacağı konusunda bilgi sahibi olması beklenmektedir.

Sonuç olarak teknolojik ilerlemeler her geçen gün artmaktadır. Geleneksel MiY uygulamaları eMIY; müşteriler ise e-müşteri doğrultusunda evrilmektedir. İşletmelerin ise değişim ve gelişmeleri yakından takip etmeleri ve iş süreçlerine bunu yansıtmaları beklenmektedir.

\section{TARTIŞMA, SONUÇ VE ÖNERILER}

Pazarlama anlayışındaki değişimlerin günümüzde tüm işletmelere yansıdığını söylemek mümkün olmamaktadır. Bazı işletmelerin ekonomik, çevresel, sosyal, teknolojik ve politik değişimleri yakından takip ettiği ve bu değişimleri müşterilerine sunacakları mal ve hizmetlere başarılı bir şekilde yansıttıkları gözlemlenmektedir. Diğer taraftan bazı işletmelerin ise pazarlamanın ilk dönemlerindeki uygulamalarına devam ettiği gözlenmektedir. Günümüzde başarılı işletmeler küresel boyutta çalışan, makro pazarlamadan yararlanan ve işletme işlevlerini bir bütünlük içinde kullanabilen işletmelerdir. Bunun amaçlanan bir yaklaşım olması gerektiği ifade edilmektedir (Akmel, 1994). Müşteri ilişkileri yönetimi, günümüzde değişimi ve gelişmeleri yakından takip eden bu doğrultuda işletme yönetimleri ortaya koyan ve başarılı bir profil çizen işletmelerin uyguladıkları iş stratejilerinden biri olarak ortaya çıkmaktadır. Uygulanmasının zahmetli ve maliyetli olmasına rağmen etkin bir şekilde uygulandığında işletme açısından pek çok avantajı bulunmaktadır. Müşteri sadakatinin artırılması, kar marjlarının yükselmesi en önemlisi ise müşteri yaşam boyu değerinin uzatılması bu avantajlardan sadece birkaçıdır.

"Değişmeyen tek şeyin değişimin kendisi" olduğu mottosunun güncelliğini yitirdiği söylenebilmektedir. Günümüzdeki işletmeler değişmekte, gelişmekte, fırsat ve tehditleri zamanında öngörerek rakiplerinden üstün konuma gelmeye çaba sarf etmektedirler. Bu bağlamda müşteri ilişkileri yönetiminin evrimini insan, süreç ve teknoloji faktörlerini inceleyerek ortaya koymanın yaşanan değişimin ne kadar hızlı olduğunu görme açısından önem taşımaktadır. İşletmelerin başarılı bir MiY için önerilen adımları takip ederek karlı sadık müşterilerinin yaşam boyu değerlerini artıracakları düşünülmektedir. 
MíY'in başarılı olabilmesi için pazardaki eğilimlerin, gelişmelerin iyi tanımlanması, izlenmesi ve iletişim odaklı düşünülmesi gibi unsurlar ön plana çıkmaktadır. Bu unsurların işletmelerin MIYY uygulamalarında gerçekleştirdikleri temel faaliyetler olduğu ifade edilmektedir. Alt faaliyetler ise müşteri pazar araştırması, hedef pazar analizleri, müşteri bölümlemesi ve veri madenciliği gibi tekniklerden yararlanarak müşteriler tanımlanmaktadır. Tanımlanan müşteri gruplarının farklı tekniklerle etkilenmesi amaçlanmaktadır.

İşletmeler MIY sürecine öncelikli olarak planlama faaliyetiyle başlamaktadır. Planlama faaliyeti içerisinde; müşteri ilişkilerine ilişkin strateji, iş planı, süreç planlaması, yatırımın geri dönüş oranı, proje önceliklendirmesi, çalışan planlaması ve uygulama öncesi bir kontrol listesi yer almaktadır.

Müşteri ilişkileri yönetimi sürecinin başarılı bir şekilde yönetilmesi için üst yönetimin katılımı önem arz etmektedir. Müşteri merkezli yönetim anlayışı MiY'in tam olarak uygulanabilmesi için üst yönetimin desteğine ve katılımına ihtiyaç duymaktadır (Chen ve Popovich, 2003). Zira, üst yönetim felsefesi haline dönüşmeyen MIYY uzun ömürlü olamamaktadır. Üst yönetim MIYY girişimleri için liderlik yapmakta, stratejik bir yön tayin etmekte ve işletmenin misyon ve vizyonları doğrultusunda süreci yönetmektedir (Herington ve Peterson, 2000). Dolayısiyla başarılı bir MİY süreci üst yönetimin katılımı ile başlamaktadır.

Sonraki aşamada, üst yönetimin katılımı önderliğinde departmanlar arası müşteri merkezli kurumsal bir kültürün oluşturulması beklenmektedir. Aksi takdirde tüm çabaların amacına ulaşmasının kolay olmayacağı düşünülmektedir. Bu bağlamda müşteri merkezli bir model; insan kaynakları, pazarlama, halkla ilişkiler ve satın alma kısacası bir işletmedeki tüm departmanların katılımı başarılı bir müşteri ilişkileri yönetimi için gerekli olmaktadır (META Group, 1998). Çünkü MIY; stratejik, analitik, işlevsel ve işbirlikçi olarak örgüt içinde uygulanmaktadır.

Daha sonraki aşamada, yukarıda sözü edilen departman temsilcilerinden oluşturulan bir MIYY proje takımın kurulması beklenmektedir. MiY proje takımı işletmelerin temel iş süreçlerini müşteri merkezli modele entegre etmede, müşteri değeri ile ilgili faaliyetleri tespit etmede veya müşteriye değer katmayan faaliyetleri çıkarma konusunda işletmeye faydalı olmaktadır (Chen ve Popovich, 2003).

Bir sonraki aşamada, MiY proje takımından oluşan müşteri merkezli model; müşteri ile ilgili veriyi toplamakta, işlemekte ve kullanılmak üzere bir iş stratejine dönüştürmektedir. Müşteri merkezli modelde her departmanın ayrı amaç ve hedefleri ortadan kaybolmakta ve tüm departmanların amaç ve hedefleri müşteri merkezinde toplanmaktadır. Dolayısıyla departmanlar arası rekabet veya anlaşmazlık ortadan kaybolmakta departmanlar müşteri merkezinde iş birliği içinde olmaktadırlar. Bu durum departmanlar arası etkili iletişimin gelişmesine olanak da sağlamaktadır. Tüm iş görenlerin motivasyonu müşteri merkezinde toplanmaktadır. Böyle bir durumda başarılı bir MIY aşamasından bahsedilmesi mümkün olmaktadır.

Son olarak MIYY girişimlerinin tüm iş görenler tarafından açık ve anlaşılır olmasına özen gösterilmesi gerekmektedir. Bu aşamada, MïY nedir ve ne için uygulanır gibi soruların cevaplarını bulması önem taşımaktadır. Bu aşama tüm iş görenlerin müşteri merkezli model içinde görevlerinin tekrar tanımlanmasını gerekli kılmaktadır. Bu bağlamda eğitim ve eğitici programlar faydalı olabilmektedir. İş görenlerin bilgi ve becerilerini artıracak eğitim programları iş görenlerin sürece katılım motivasyonları artıracaktır. İş değerlendirme, ödül programları veya sistemleri ve terfi gibi uygulamalar ile MiY girişimlerini uygulamak kolay hale gelmektedir. 
Özetlemek gerekirse başarılı bir MiY'de öncelikle üst yönetimin felsefesi önderliğinde bir proje takımının kurulması sonrasında müşteri merkezli stratejilerin oluşturulması, ardından işlevsel rollerin tanımlanması, daha sonra süreçlerin yönetilmesi ve en sonunda eğitim programları ile zenginleştirilmiş teknoloji temelli bir yaklaşım sergilenmelidir.

Bilgi çağında işletmelerin tüketicilere elektronik temas noktaları ile ulaşmaları gerekmektedir. $\mathrm{Bu}$ noktada akıllı telefonlar, tabletler ve kiosklar (elektronik terminal) kullanılabilir. Teknolojinin sunduğu avantajlar doğrultusunda zenginleştirilmiş gerçeklik uygulamaları tüketicilere farklı bir deneyim yaşama imkanı sunacaktır.

Değişen pazar koşulları sebebiyle pazarlama karması elemanlarının (ürün, fiyat, dağıtım, tutundurma) müşteriyi merkeze alarak oluşturulması sağlanmalıdır. Müşteri istek, ihtiyaç ve beklentileri izlenmeli ve bu doğrultuda ürün ve hizmet üretilmelidir.

İşletmelerin müşterilere karşı bakış açılarının değişmesi sağlanmalıdır. İşletmeler için müşterinin anlamı kısa vadede değil uzun vadede bir iş ortağını ifade etmelidir. Bu noktada MİY süreçleri yeniden tasarlanmalıdır.

Müşteri şikayetleri konusu ayrıca ele alınmalıdır. Çeşitli yazılım programları oluşturulmalı ve söz konusu şikayetler sistemsel olarak analiz edilmelidir.

İlişkisel pazarlama içerisinde yer alan Mí' de müşteriler ile iletişim kurmak ve bu iletişimi sürdürmek oldukça önemlidir. Bu konuda doğru yerde, doğru zamanda ve doğru iletişim aracı ile müşteriye ulaşmak gerekmektedir.

Son olarak, işletmeler işgörenlerine belirli periyodlarla müşteri değeri konusunda eğitimler vermelidir. MiY'in bir felsefe olduğu unutulmamalı ve bu felsefenin tüm örgüt çalışanları tarafından doğru anlaşılması sağlanmalıdır.

\section{KAYNAKÇA}

Adıgüzel, O., Batur, H. ve Ekşili, N. (2014). Kuşakların Değişen Yüzü ve Y Kuşağı ile Ortaya Çıkan Yeni Çalışma Tarzı: Mobil Yakalılar, Süleyman Demirel Üniversitesi Sosyal Bilimler Enstitüsü Dergisi, (19): 165-182.

Akmel, J. (1994). Turizm İşletmelerinde Pazarlama Yönetimi. İstanbul: Marmara Üniversitesi Sosyal Bilimler M.Y.O. Yayınları.

Alwin, D. F. (2002). Generations X, Y and Z: Are They Changing America, American Sociological Association, Contexts, 42(1): 42- 51.

Bresman, H. and Rao, V. D. (2017). A Survey of 19 Countries Shows How Generations X, Y, and Z Are -and Are'nt- Different. [Online] https://hbr.org/2017/08/a-survey-of-19-countries-shows-

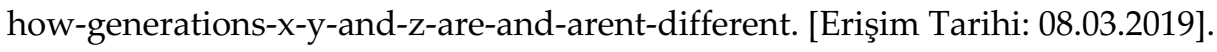

Cemalcılar, İ. (1986). Pazarlama. İstanbul: Beta Basım Yayım Dağıtım A.Ş.

Chen, I. J., and Popovich, K. (2003). Understanding Customer Relationship Management (CRM) People, process and technology. Business Process Management Journal, 9(5): 672-688.

Chiang, W. Y. (2018). Applying data mining for online CRM marketing strategy: An empirical case of coffee shop industry in Taiwan. British Food Journal, 120(3): 665-675.

Garrido-Moreno, A., and Padilla-Meléndez, A. (2011). Analyzing the Impact of Knowledge Management on CRM Success: The Mediating Effects of Organizational Factors. International Journal of Information Management, 31(5): 437-444. 
Gupta, G., Aggarwal, H., and Rani, R. (2016). Segmentation of Retail Customers Based on Cluster Analysis in Building Successful CRM. International Journal of Business Information Systems, 23(2): 212-228.

Jianrui, J. (2011). The Y Factor: Managing the New Generation of Soldiers. Journal of The Singapore Armed Forces, 39(4): 53-59.

Karafakığlu, M. (2005). Pazarlama İlkeleri. (1. Basım), İstanbul: Literatür Yayınları.

Kırım, A. (2003). Strateji ve Bire-Bir Pazarlama CRM. (3. Basım), İstanbul: Sistem Yayıncllı.

Kotler, P., Kartajaya, H. and Setiawan, I. (2014). Pazarlama 3.0. (Çeviren, Dündar, K.), (4. Basım), İstanbul: Sinpaş GYO Kitapları.

Köse, N. ve Yengin, D. (2018). Dijital Pazarlamadan Fijital Pazarlamaya Geçişe Örnek Olarak Artırılmış Gerçeklik ve Sanal Gerçeklik Uygulamalarının Pazarlama Üzerindeki Katkılarının İncelenmesi, İstanbul Aydın Üniversitesi Dergisi, 10(1): 77-111.

Law, R., Fong, D. K. C., Chan, I. C. C., and Fong, L. H. N. (2018). Systematic Review of Hospitality CRM Research. International Journal of Contemporary Hospitality Management, 30(3): 1686-1704.

Lower, J. (2008). Brace Yourself Here Comes Generation Y, Critical Care Nurse, 28 (5): 80-85.

META Group (1998). The Seven Deadly Sins of CRM Implementation, META Group Report, November.

Mucuk, İ. (1997). Pazarlama İlkeleri. (8. Basım), İstanbul: Türkmen Kitapevi.

$\mathrm{Ng}$, A. (2016). Hiring Your First Chief AI Officer, Harvard Business Review, [Online] https://hbr.org/2016/11/hiring-your-first-chief-ai-officer. [Erişim Tarihi: 08.03.2019].

Peppers, D., Rogers, M., and Dorf, B. (1999). Is Your Company Ready for One-to-One Marketing. Harvard Business Review, 77(1): 151-160.

Pohludka, M., and Štverková, H. (2019). The Best Practice of CRM Implementation for Smalland Medium-Sized Enterprises. Administrative Sciences, 9(1): 22.

Rodriguez, M., Peterson, R. M., and Krishnan, V. (2018). Impact of CRM technology on sales process behaviors: empirical results from US, Europe, and Asia. Journal of Business-to-Business Marketing, 25(1): 1-10.

Umamaheswari, P., Pandian, M. J. and Venkateswari, P. (2018). Classifying Customers to Improve Retailer's Profit for CRM. International Journal of Pure and Applied Mathematics, 118(20): 3137-3148.

Zablah, A. R., Bellenger, D. N. and Johnston, W. J. (2004). An Evaluation of Divergent Perspectives on Customer Relationship Management: Towards A Common Understanding of An Emerging Phenomenon. Industrial Marketing Management, 33(6): 475-489. 